\title{
Agricultural Trade Reform after the Asian Recession: A Bridge too Far?*
}

\author{
Rod Tyers \\ Faculty of Economics and Commerce \\ Australian National University \\ ACT 0200, Australia \\ Email: rod.tyers@anu.edu.au \\ Phone: 61-2-6249 3364 \\ Yongzheng Yang \\ National Centre for Development Studies \\ Australian National University \\ ACT 0200, Australia \\ Email: yongzheng.yang@anu.edu.au
}

Phone: 61-2-6249 0431

\section{WORKING PAPERS IN ECONOMICS AND ECONOMETRICS No. 378 Faculty of Economics and Commerce \\ and \\ Economics Program, Research School of Social Sciences \\ Australian National University}

June 1999

National Library of Australia Card

and ISBN No. 0868313785

* Thanks are due Robert McDougall, Tom Hertel, Ron Duncan and Kym Anderson for useful discussions in the formative stages and to Shujuan Lin for providing access to the most recent OECD data on producer subsidy equivalents. Constructive comments on an early draft were provided by Sam Laird, Steve McCorriston, Robert Read and other participants at the annual conference of the UK International Economics Study Group in Birmingham, September 1999. 


\title{
Agricultural Trade Reform after the Asian Recession: A Bridge too Far?
}

\begin{abstract}
The collapse of the heretofore most rapidly growing Asian developing economies, combined with the long recession in Japan, caused northern agriculture to endure the combined effects of declining commodity prices and rising domestic costs associated with real appreciations against major Asian trading partners. The redistribution of global investment associated with the Asian recession is likely to be long lasting. In this paper global general equilibrium analysis is employed to quantify the effects of this redistribution. Although the economies of the north prove to be net gainers, northern farmers lose by more than any other non-Asian group. Rising protection has insulated some groups of northern farmers but this has exacerbated the burden of adjustment on others. These losses are substantial compared with those that would be incurred by currently protected farmers were the millennial negotiations to achieve a reduction of existing distortions by half. The political costs of achieving an agricultural trading system more liberal than that of the mid-1990s must therefore be higher following the Asian recession.
\end{abstract}

\section{Introduction}

As technical progress in communications and transport made capital and skill progressively more mobile internationally, governments around the world sought a more general liberalisation of their economies to attract these mobile resources. Such reforms took place in both the developed and the developing world and in the latter, the leading region was undoubtedly East and Southeast Asia. There, relative capital scarcity combined with high savings rates and perceived high rates of return on investment, saw an extraordinary rate of capital accumulation. All the countries of this region have comparatively high population densities and so, as capital accumulated, their comparative disadvantage in agricultural products increased. Substantial growth in imports of agricultural products and other raw materials followed.

Since 1997, Asian growth has stalled following a combined financial and currency crisis that brought on what we will call the "Asian recession". ${ }^{1}$ Several of the developing economies that had earlier been major contributors to both Asian growth and commodity imports experienced very substantial contractions associated with a surge of insolvencies

\footnotetext{
${ }^{1}$ Subsequent but associated "crises" in Latin America, Eastern Europe and in Russia have magnified the effects of the initial shocks in Asia. We focus on the effects of the Asian shocks only.
} 
following capital flight and unexpectedly large currency depreciations. ${ }^{2}$ This saw their capital accounts shift from surplus to deficit and necessitated dramatic contractions in imports.

Accordingly, global demand for agricultural commodities contracted and international commodity prices fell.

In the north, some governments did not pass these price declines through to farmers and so the level of agricultural protection rose and the bridge to reforms envisaged during the Uruguay Round has grown longer. Even in countries whose governments have allowed the effects of the Asian recession to pass through to their farmers further trade reform will have to come on top of already costly adjustment. Moreover, the effects of the Asian recession are unlikely to be fully reversed by the inevitable recovery. Recent research suggests that there is good reason to expect this eventual recovery to extend well into the negotiation period of any Millennium Round. ${ }^{3}$.

In this paper we first develop the argument that the reallocation of global investment away from the affected Asian economies will be long lasting. We then examine the magnitudes of the structural adjustments that liberalisation would have imposed on protected agricultural sectors in 1995 and explore the extent to which these have been magnified by the Asian recession. Although we use global general equilibrium analysis to simulate the recession ${ }^{4}$ we make no attempt to reproduce the short run dynamics of the crisis. ${ }^{5}$ Instead, our analysis is comparative static, taking as our starting point the real shocks that emerged in its wake. In the short run, these included a severe contraction of domestic investment (as home savings fled abroad and foreign savings in Asia were withdrawn) and the temporary unemployment of capital as many Asian firms foundered under the escalated cost of foreign borrowings and the credit crunch that followed. ${ }^{6}$ Recent evidence suggests that a considerable number of firms in the most affected countries were rendered insolvent, and a larger number illiquid, ${ }^{7}$ and that this explains the bulk of the initial contractions in output.

\footnotetext{
${ }^{2}$ See Corsetti et al. (1998), McLeod and Garnaut (1998), Goldstein (1998), Radelet and Sachs (1998) and Wong (1998).

${ }^{3}$ See Krugman (1999b) and Yang and Tyers (1999).

${ }^{4}$ Earlier applications to the Asian recession include those by Adams (1998), Coyle et al. (1998), Noland et al. (1998) Suryahadi (1998) and Yang and Tyers (1999).

${ }^{5}$ Although the events that precipitated the crisis are now fairly well understood (theoretical treatments of the underlying behaviour include those by Chang and Velasco, 1998, and Krugman, 1999a), the best dynamic global macroeconomic models to date still do not fully endogenise the capital flight of 1997 ( McKibbin, 1998a, b).

${ }^{6}$ These related impacts are foreshadowed by Corbett and Vines (1999).

${ }^{7}$ See World Bank (1999).
} 
Our emphasis here is on the medium run effects of the recession. ${ }^{8}$ We imagine that property rights issues are eventually resolved but that there is a longer lasting reallocation of the world's savings away from Asia. We estimate the effects of this reallocation on trade in agricultural products and, ultimately, on real returns to the assets of northern farmers. The results are then compared with the corresponding effects of an indicative reduction of all agricultural distortions by 50 per cent. Where the effects of the Asian recession on northern farmers have been muted by insulating trade policies, we note that such policies have raised protection levels and therefore increased the scale of structural changes that would have to accompany further agricultural trade reform. In Section 2 a brief review of the Asian recession is offered and our reasons spelled out for expecting the medium run effects of the recession to be long lasting. A preliminary assessment of the recession's importance for agricultural markets is also offered. Section 3 then introduces the model we use and provides a summary of its structure and behaviour. Our analysis of the Asian recession experiments is detailed in Section 4 and its potential interaction with trade reforms is discussed in Section 5. Section 6 then offers conclusions.

\section{The Asian recession and agricultural markets}

\subsection{The recession}

The events of 1997 are already well documented in a number of studies. ${ }^{9}$ Our interest is in the associated real shocks and their implications for agricultural commodity markets. We include Japan in our analysis despite important differences in the character of its recession from those elsewhere in developing Asia. ${ }^{10}$ The bursting of the 1980s asset bubble there caused a decline in investment that accelerated in 1997 in spite of a macroeconomic policy that maintained very low short-term interest rates. Private consumption in Japan remained comparatively stable during the 1990s but it declined in the crisis period. The associated rise in savings combined with the decline in investment has further expanded Japan's current account surplus. In addition, a trend toward lower working hours, combined with the recent implementation of a standard 40-hour week caused a decline in total labour

\footnotetext{
${ }^{8}$ The short and medium run effects of the Asian recession are compared by Yang and Tyers (1999).

${ }^{9}$ See $\operatorname{IMF}(1998,1999)$ and the publications cited in footnote 3.

${ }^{10}$ The financial origins of the Japanese recession are discussed in Horiuchi (1998).
} 
hours and an associated reduction in output per worker. ${ }^{11}$ Thus, Japan's trade surplus rose while its GDP fell. ${ }^{12}$

In the most affected countries of developing Asia the scale of the contractions was proportionally larger. ${ }^{13}$ Worst hit have been Indonesia and Thailand but the economies of Malaysia and Korea also contracted substantially. The crisis in these countries began in Thailand in mid-1997 following a period during which export performance had begun to falter and foreign currency denominated debt to accumulate. As doubts arose about the government's commitment to honour implicit guarantees to maintain the nominal exchange rate, a capital flight ensued resulting eventually in a very substantial currency depreciation. The sharp rise in domestic debt and debt service costs that followed precipitated the associated financial crisis. ${ }^{14}$ Fear of similar developments appears then to have been self-fulfilling in near neighbours Indonesia and Malaysia. As savings were withdrawn from these economies, and their currencies depreciated, asset prices fell and considerable wealth was lost. Private consumption fell and savings rose. Very large declines in domestic investment combined with the rise in savings to create substantial capital account deficits counterbalanced on the current account side by collapses in imports.

One year after the onset of the crisis, export values had not fallen, though neither had they yet begun to rise. ${ }^{15}$ Of course, considering the substantial currency depreciations these countries experienced, this does imply a rise in export volumes offset by a fall in US\$ export prices. ${ }^{16}$ Moreover, the growth of competing exports from China began to decelerate as the Chinese currencies appreciated against those of recessed developing Asia. Although the Chinese and Hong Kong governments held fast to their nominal exchange rates against the US dollar, the contractionary policies required to achieve this depressed domestic consumption and raised saving. Their domestic price levels fell and their real exchange rates depreciated

\footnotetext{
${ }^{11}$ See Bayoumi and Towe (1998).

${ }^{12}$ See IMF (1988), Chapter IV.

${ }^{13}$ Their contributions to global GDP are smaller in magnitude than that of Japan, however. The 1998 contraction of the Japanese economy by 2.8 per cent took US $\$ 114$ billion off global output. This compares with a total of US\$83 billion from the combined contractions in the affected developing Asian countries. Although PPP based comparisons would enhance the latter figure, they would not nullify the point of the comparison.

${ }^{14}$ A clear summary of these events is provided in the retrospective by Corbett and Vines (1999).

${ }^{15}$ See IMF (1998) Table 2.6.

${ }^{16}$ Interestingly, however, since Japan has been an important destination for exports from developing Asia, holding the line on export values has meant a considerable redirection of exports toward the European Union and the United States.
} 
against trading partners in the north even while they appreciated against competitors elsewhere in developing Asia. ${ }^{17}$

For the most affected Asian economies, the primary real shocks were of two types. First, as savings fled domestic investment declined. In Japan, where the process was more gradual, investment fell by about a tenth in the two years from late $1997 .{ }^{18}$ In the most affected economies of developing Asia, however, the initial panic of 1997 was so great that domestic investment declined by as much as half. Domestic capital goods and construction demand collapsed and private consumption demand also fell, driven by the associated wealth effects of asset price declines. Imports therefore fell dramatically.

The second of the real shocks was a further short run decline in domestic production in the affected economies. Because the credit squeeze was greatly exacerbated by an associated currency crisis and hence a blowing out of dollar denominated debt service costs, there was a high incidence of illiquidity and insolvency. ${ }^{19}$ This was the more so in developing Asia because of the rapid expansion of private sector credit there during the early 1990s. In the decade to 1995, for example, private sector credit as a proportion of GDP tripled in Indonesia and doubled in Thailand. ${ }^{20}$ Equity markets were comparatively underdeveloped and investment during the period was financed primarily by debt. Debt-equity ratios of Korean domestic manufacturing firms in the mid 1990s, for example, were double those of manufacturing firms in the US. It was therefore inevitable that the substantial rise in debt service costs would drive more than the usual proportion of firms in the most affected economies into insolvency. ${ }^{21}$ This was the principal cause of the contractions in output experienced in developing Asia in the first year following the onset of the crisis. We examine and compare these real shocks in Yang and Tyers (1999). In this paper we take the same approach but focus on the more long lasting "medium run" shock, the flight of savings from Asia or the reallocation of global investment away from Asia.

\subsection{Why the "medium run" effects of the recession might be long lasting}

\footnotetext{
${ }^{17}$ See Huang and Song (1999).

${ }^{18}$ According to IMF(1998), Table 3, gross fixed capital formation in Japan declined by 3.5 per cent in 1997 and was forecast to decline by 7.2 per cent in 1998 .

${ }^{19}$ See the discussion of this in Corbett and Vines (1999). This effect is also noted in Lane et al. (1999).

${ }^{20}$ See IMF (1998, Ch.3) Table 3.8.

${ }^{21}$ This is borne out in a recent World Bank survey of 3,700 companies in the worst affected economies (World Bank, 1999) as reported in Asiaweek, 16 April 1999.
} 
In support of our conclusion that the medium run effects of the Asian recession will last into the millennium round negotiation period, we offer four points. First, through the initial two years of the recession the crisis induced shifts in Asian balances of payments in favour of capital account deficits (current account surpluses) have abated only slowly in the affected Asian economies. Currencies and stock markets in many affected countries have recovered somewhat but even where countries ran capital account surpluses (current account deficits) prior to 1997, the apparent trend is toward retention of deficits. ${ }^{22}$ Second, although political regimes have changed since the onset of the recession in most affected countries, financial reforms and the restructuring of the financial services sector have been very slow in all.

Third, much of the investment in the affected countries through the mid 1990s was financed by borrowing abroad with private domestic assets as collateral. In the crisis, lenders were burned and a substantial part of the private wealth that facilitated the investment has been lost. ${ }^{23}$ Moreover, the changes of political regime that followed should combine with the anticipated financial reforms to make it more difficult than before for a select few individuals to accumulate private wealth at the same rate as before. And finally, there is the observation by Krugman (1994) and others, that evidence of diminishing returns to capital had begun to appear in East Asia during the early 1990s. The returns may simply not be there to justify the share of the world's investment achieved in the pre-recession period. We conclude, therefore, that the changed pattern of global savings and investment is likely to endure, at least through the early stages of the WTO's "Built-in Agenda", to commence in 2000.

\subsection{Asia and agricultural markets}

The affected economies of Japan, China and Southeast Asia contributed a quarter of global GDP in the mid 1990s. Even if retained within the region, a recession in these countries must affect the rest of the world substantially. But the significance of the region for agricultural markets goes beyond this. Over the two decades prior to the recession, as these economies opened to trade their poor endowments of land per capita saw them transit from net exporters of commodities to net exporters of manufactures and importers of agricultural

\footnotetext{
${ }^{22}$ See the Economist (1999; August 21-27: 14-16).

${ }^{23}$ Krugman (1999b) has referred to this as the "decapitation of the entrepreneurial class". He offers a theoretical model of the process, in which the denomination of debt is explicit, in Krugman (1999a).
} 
products. For the economies most affected by the Asian recession, by the mid 1990s two thirds of these agricultural imports were from the US, the EU, Canada and Australasia. More importantly, however, the combined imports of the recessed developing economies of Asia, Japan and China made up about a third of US total exports. Yet their imports of agricultural products from the US made up half of that country's total agricultural exports. The corresponding shares for the EU and Australasia were 20 and 57 per cent, respectively. ${ }^{24}$ Any decline in Asian imports, or realignment of currencies between Asia and the northern economies, was therefore bound to have a substantial effect on northern farmers.

Indeed, the Asian recession did affect northern farmers directly, through trade in the commodities they produce. This is evident from the traded commodity prices plotted in Figure 1. These include two cereals, a natural fibre and sugar, all deflated by the US GDP deflator. Since 1980 there are only two occasions on which all the prices turned downward simultaneously. The first was during the early 1980s, when the high interest rate policy of the early Reagan period caused a substantial real appreciation in the US relative to the rest of the world. This was the period that precipitated the Uruguay Round of trade negotiations and, in particular, the priority given in that round to an agreement on agriculture. ${ }^{25}$ The second was between 1997 and 1998, again associated with a real appreciation in the north, this time relative to Asia and some other developing countries.

The effect on northern farmers not only took the form of commodity price changes and a wider real appreciation. ${ }^{26}$ It also changed the composition of international trade in goods that compete with agriculture for resources. A clear view of both the direct and indirect effects requires an accurate representation of factor markets in the north and hence of the proportions in which primary factors and inputs are used across industries. In this the EU is fairly typical. Its 1995 factor proportions are summarised in Table 1. Broadly, agriculture is land and labour intensive, mining is capital intensive and manufacturing labour intensive. Typical of all the northern industrial economies, however, the dominant services sector is capital intensive relative to manufacturing and it comprises two subsectors, one of which is intensive in unskilled labour while the other combines relatively balanced shares of the three

\footnotetext{
${ }^{24}$ These statistics stem originally from the UN Commodity Trade Statistics. Our secondary source is, however, the GTAP Version IV Database. See McDougall et al. (1998).

${ }^{25}$ See OECD, 1998.

${ }^{26}$ The indirect effects of real exchange rate changes on agriculture were noted by Krueger, Schiff and Valdes (1991) and, more recently, by Schiff and Valdes (1998).
} 
mobile factors. Agriculture's labour intensity proved important in affecting the position of farmers for, as it turned out, the Asian recession raised labour demand in the north. Thus, northern farmers were not only to be hurt by declines in both Asian agricultural imports and traded commodity prices but also by a rise in the real cost of their most important mobile factor of production. We now turn to our approach to the quantification of these effects.

\section{The Model}

Our interest is in a medium run in which labour is mobile between sectors while physical capital is immobile. The model used must accommodate this in combination with an open capital account in each region and therefore an explicit treatment of savings and investment. We use an adaptation of the GTAP global general equilibrium model. ${ }^{27}$ Its analytics are summarised in Table 2. As a starting point, it offers the following useful generalisations: (i) a capital goods sector in each region to service investment, (ii) explicit savings, albeit at an exogenous rate, in each region combined with open regional capital accounts that permit savings in one region to finance investment in others, (iii) multiple trading regions, goods and primary factors, (iv) non-traded goods and services, (v) product differentiation by country of origin, (vi) empirically based differences in tastes and technology across regions, (vii) non-homothetic preferences, and (ix) explicit allowance for transportation costs and policy distortions.

For the corresponding database, we use the GTAP Version 4 database for 1995, aggregated into the regions listed in Table $3 .^{28}$ Note that we use the aggregate, "recessed developing Asia" to represent the most seriously affected Asian region. Although it excludes less affected China, within this region there is considerable variance in the degree to which countries were affected by the recession. The Asian recession shocks we impose are therefore averages across the region and do not reflect the severity of the effects in such individual economies as Indonesia.

Households and firms in the model consume a composite of goods and services that is a blend of home products and imports the composition of which depends on relative prices and an elasticity of substitution. In turn, imports are a blend of the products of all regions and its

\footnotetext{
${ }^{27}$ For a detailed description of the standard version of this model, see Hertel (1997). Our modifications to the structure of the model are detailed in Yang and Tyers (1999). They are principally changes to the factor demand structure. For the present purpose, though, they include the sector specificity of capital in all regions.

${ }^{28}$ For a detailed description of the database, see McDougall et al. (1998).
} 
composition depends on regional trading prices and a further elasticity of substitution. This structure facilitates the departures from the law of one price that tend to occur even in tradeable goods sectors in the short and medium run. ${ }^{29}$ For this reason, we do not adopt the practice common amongst GTAP users of choosing larger than the standard elasticities of substitution in all industries when doing long run comparative static analysis. ${ }^{30} \mathrm{We}$ do, however, use larger than the standard elasticities for the comparatively homogeneous agricultural products. The elasticities used are listed in Table 4.

Our adaptation of the model involves changes to its intermediate input and labour demand structure. In particular, to accurately represent substitution between inputs and primary factors, we have made output a CES composite of intermediate products and primary factors. Also, to better reflect factor market impacts of external shocks, we have introduced a further composite of skilled and unskilled labour. This allows the two types of labour to be differently substitutable for each other than each is substitutable for the other mobile factor, capital. $^{31}$ Finally, the short run nature of the Asian crisis requires a closure in which capital is industry specific in all regions.

\section{Medium Run Effects of the Asian Recession}

\subsection{The medium run Asian recession experiment}

Our construction of Asian recession shock follows Yang and Tyers (1999). Since further trade negotiations will take place in the more distant aftermath of the recession, for our present purpose we emphasise the medium run in which property rights issues are resolved and capital is no longer idled in developing Asia and Japan. The essential element of the medium run story is the continued reallocation of global investment away from the affected countries. The exercise undertaken here differs from that in Yang and Tyers, however, not only because of our emphasis in this paper on the medium run. In this analysis, both the country and commodity aggregates used also differ and the role of China is accounted for more explicitly.

\footnotetext{
${ }^{29}$ The early literature on real exchange rate changes tended to focus on associated relative price changes where tradeable goods prices retained parity with international trading prices. More recently it has become certain that short run departures from the law of one price occur across all tradeable goods sectors. See Engel (1999). ${ }^{30}$ See the discussion of long run shocks in Gehlhar (1994), Gehlhar et al. (1994) and Hertel et al. (1996, Appendix C: 212).

${ }^{31}$ In further research, we experiment with two alternative nested CES structures that allow experiments with different mixes of substitutability and complementarity across primary factors and intermediate inputs.
} 
Although our focus is on the medium run, we use throughout a version of the model that restricts intersectoral capital mobility in all regions. Returns to capital therefore vary across industries. We cannot escape some attention to the short run, however, because our model does not have intertemporal optimisation by households or firms and we use the short run analysis to establish benchmark average savings rates in recessed developing Asia and Japan. Since some data are now available for the affected countries for 1998, we can observe levels of investment and output as well as current account imbalances in the immediate aftermath of the crisis. Because these data are incomplete, we use them to formulate short run shocks and apply the model to calculate the implied average rates of saving. These are then held constant in our medium run analysis. ${ }^{32}$ Because Yang and Tyers present the details of the short run shocks we do not repeat them here.

In the medium run, debt workouts have resolved property rights issues and capital is no longer unemployed in recessed developing Asia and Japan. Capital remains immobile between industries, however. As capital utilisation rates return to benchmark levels, the short run retreat of labour to agriculture is reversed and factor productivity in agriculture returns to its reference levels. GDP levels in recessed developing Asia and Japan therefore approach their pre-recession benchmarks. Nonetheless, we set investment, relative to GDP, to remain at 1998 levels in these two regions. Their current account balances are restored to endogeneity to ensure consistency with the capital account. This allows the recovery in their national incomes to further raise total savings and hence for the trade surplus to widen as growth in exports underwrites their recoveries. ${ }^{33}$

China is added as a distinct region in this analysis and its behaviour is represented as "in between" that of the recessed economies and those of the north. Recent data on China's domestic investment and its balance of payments is incomplete and, probably, highly inaccurate. We are guided by a rise in declared official foreign reserves of US\$ 5 billion during 1998, and evidence of substantial domestic deflation, to hypothesise a rise in China's current account surplus by this amount. ${ }^{34}$ Domestic investment is made endogenous to

\footnotetext{
${ }^{32}$ It is assumed that, during the long process of recovery, these high savings rates will be maintained to enable the recessed economies to eventually pay off their crisis-enhanced foreign debt.

${ }^{33}$ Although there is evidence that investment has begun to rise again in developing Asia, the effect this might have had in reducing the capital account deficit there is probably balanced by savings changes that support a rise in debt service flows on the current account. Since our model allows no interregional factor ownership, there are no interregional flows of capital returns. For this reason, we maintain the same investment levels and savings rates as in the short run.

${ }^{34}$ See Huang and Song (1999).
} 
equalise regional average "expected rates of return" 35 but the average rate of saving is made endogenous to ensure consistency with the exogenous current account change. The full set of shocks and closures adopted in this medium run scenario are detailed in Table 5.

\subsection{Effects with full pass-through in the north}

Our main simulation assumes ad valorem tariff and export subsidy equivalents in the north remain unchanged. This implies that proportional changes in international prices are passed through to northern farmers and consumers. That this might not have been the case is discussed in the next subsection.

The simulated medium run effects of the Asian recession on the balance of payments in each region are displayed in Table 6. As foreshadowed, investment falls and savings rise in both recessed developing Asia and Japan and these changes are balanced by substantial declines in imports and rises in exports. The allocation of investment across the non-recessed regions is endogenous in the model. ${ }^{36}$ Investment rises in China but, because the current account surplus is constrained to rise by US $\$ 5$ billion, the average rate of savings adjusts to ensure that total savings increase by this much more than the change in investment. All the other regions experience enlarged investment and (fixed rate) savings rises slightly with national income in each case. In the northern regions, substantial shifts in their capital accounts toward surplus are matched by shifts in their current accounts toward deficit which take the form of very substantial rises in imports and smaller falls in exports.

Also shown in Table 6 are our estimates of the associated real exchange rate and terms of trade changes. All the other regions appreciate against the two recessed ones, which we refer to hereafter in combination as "recessed Asia". Note, however, that China's real appreciation relative to the recessed regions is smaller than the others and hence it experiences a real depreciation against its northern trading partners. As exports from recessed Asia become cheaper, China and all the northern regions enjoy terms of trade gains, of which the US experiences the largest. The associated changes in agricultural commodity prices are provided in Table 7. In recessed Asia, substantial real depreciations cause real increases in both import and domestic producer prices. Correspondingly, reduced exports to depressed

\footnotetext{
${ }^{35}$ See Hertel and Tsigas (1997: 54-60).

${ }^{36}$ Policy induced differences in the accessibility of domestic capital markets across regions are not represented. As it turns out, the rise in investment is most substantial in Europe and, therefore, so also is the rise in European imports.
} 
Asia from the north, combined with the northern real appreciations, cause both import and producer prices to fall there. The declines are smaller than the rises in depressed Asia, however, because Asia has a smaller share of the north's trade than the north has of Asia's.

In the intermediate case of China, agricultural import prices rise relative to the local GDP deflator. This is because China mainly imports agricultural products from the north, against which it experiences a real depreciation of about four percentage points. Note, also, that in the north the magnitudes of changes in import prices are larger than the corresponding changes in producer prices. This is because home products are differentiated from imports and so the switching by consumers from home products to imports is incomplete. This affords farmers in the north a measure of "natural" insulation. In the case of the EU, for example, the declines in farm prices are between half and two thirds of the corresponding border price changes.

The effects on sectoral output are detailed in Table 8. The broad pattern is for the tradeable goods sectors to be advantaged in recessed Asia and disadvantaged in China and the north. In association with the increased levels of investment in the north, demand for northern capital goods and hence indirect demand for relatively untraded services rise substantially. The expanding services sectors absorb labour released by the tradeable goods sectors. Most notable, however, is that the contractions across the north's tradeable goods sectors are nowhere as large as they are in agriculture. In the US, the dominant contractions are in cereals and other crops, in the EU in cereals and in Australasia they are in "other crops" and

37 Thus, although the real appreciations relative to recessed Asia accompany terms of trade gains for the northern regions and overall expansions in GDP, farmers are the principal losers.

The distributional effects of these changes in the north are best illustrated by the associated changes in unit factor rewards there. These are presented in Table 9. Workers, who are intersectorally mobile in our analysis, are gainers because they move to the more prosperous and expanding services sectors. This is not a particularly costly adjustment in the industrialised north, since the services sectors there are already very much larger than the contracting tradeable goods sectors. The rise in real wages is a further cost to farmers, however, whose activities are relatively labour intensive. With real product prices falling and the real price of the key input rising, the squeeze on farmers causes the real unit rewards of 
land and other natural resources to fall by relatively large margins. Turning to the real reward to capital, average real returns rise in the north but this is driven by rises in the very large services sectors. There are falls in the real rates of return on capital specific to all the tradeable goods sectors. Again, however, the declines are largest in the agricultural sector. In the EU, for example, the falls in capital returns are three-fold larger than those in other tradeable goods sectors. Outside recessed Asia, northern farmers are clearly the sectoral group most hurt by the recession.

\subsection{Why farmers lose most in the north when recession effects are passed through}

Superficially, one might expect Engel's Law to ensure that the substantial contractions in income in Asia cause consumption there of agricultural products to fall by less than that of manufactures. This leads to the presumption that the north's agricultural exports would decline by less than the corresponding manufactured exports and hence that manufacturers would lose most. In fact, the north's agricultural exports to Asia decline by more than do its manufactured exports.

The reasons for this begin with the contractions in investment and consumption in recessed Asia. As we saw in Table 8, medium run aggregate real incomes in these regions are almost at their benchmark levels. Consumption contracts a little as savings rise but the income effects on consumption, which should bolster relative demand for agricultural products, are slight. More than offsetting this is the effect of the surge in manufactured exports from these regions at the onset of the recession, driven by the decline in private consumption. To feed these exports, as indicated by Table 8, manufacturing output rises above its pre-recession levels in the three affected Asian regions. This increased manufacturing production draws in imports of intermediate inputs and these comprise mainly manufactures. The net decline in manufactured imports is therefore smaller than that in agricultural imports. That this should be true is clear from Table 10, which lists both the sectoral contribution to the exports of the effected Asian regions and the share of imported manufactures in input costs. In all three Asian regions, exports are dominated by manufactures. And in each case, manufacturing costs have the largest import intensity with imported manufactures predominant amongst imported intermediate inputs.

${ }^{37}$ These results suggest more uniformly adverse impacts on US farmers than those of Coyle et al. (1998). 
But the story does not end with the north's agricultural exports to recessed Asia declining by more than its manufactured exports. As indicated in Table 7, in the US, the EU and Australasia agricultural import prices fall by less than the import prices of manufactures. This is because, as the elasticities of substitution in Table 4 attest, manufactures are more highly differentiated across regions than agricultural products and so the surge in Asian exports tends to push down traded Asian manufactures prices by more. Of course, this also means that changes in the prices of imported manufactures in the north are passed through with more natural insulation than similar changes in agricultural import prices. In the end, as Table 7 shows, the declines in northern producer prices are larger for agriculture than for the other traded goods, and particularly manufactures.

\subsection{The effects without full pass-through in the EU and the US}

Throughout this analysis we have assumed that ad-valorem tariff and export subsidy equivalents were held constant by northern governments. That this is not, in fact, the case is indicated by the OECD's annual estimates of agricultural producer subsidy equivalents for the EU and the US (OECD, 1999), shown in Table 11. These rose between 1997 and 1998, just as international commodity prices took their Asian recession driven dip. Indeed, the power of the overall average ad valorem producer subsidy equivalent for the EU rose in 1998 by 22 per cent, while that for the US rose by 11 per cent. It is likely, therefore, that farmers in these and some other northern regions were partially, if not completely, insulated from the Asian recession shock by the rise in trade distortions.

That ad valorem agricultural protection rates should have risen in spite of the Uruguay Round Agreement on Agriculture (URAA) is not surprising. The three main commitments to reform under this agreement required tariffication, market access and a ceiling on an aggregate measure of support (AMS). For many northern regions, tariffs were set at prohibitive levels. Moreover, at least in the case of the EU, these tariffs were specific, so that, when international prices fell the power of the tariff (and the ad valorem protection rate) rose. ${ }^{38}$ Market access was ensured through the establishment of "tariff rate quotas" (TRQs) that offered lower tariffs on a limited quantity of imports. Regions took a variety of approaches to the allocation of these TRQs, however, and they have often been unfulfilled. Finally, many northern regions were able to have a substantial part of their support for farmers 
classified into the "green" and the "blue" boxes which, under Article 13 (the "peace clause") will not be contestable until 2003. ${ }^{39}$ This meant that the AMS constraint did not bind in the mid 1990s and scope for increased overall support remained.

To examine the effects of an insulating rise in northern agricultural protection, we reran the experiment of the previous section. This time we assumed that the governments of the EU and the US would hold real farm prices constant (relative to their respective GDP deflators) and allow agricultural trade distortions to rise. The power of US and EU agricultural import tariff and export subsidy equivalents then rises by between three and five per cent. The earlier declines in the real unit reward of land and capital in agriculture are largely arrested in these two regions. Because this change of policy reduces the share of adjustment borne by the US and the EU, however, traded agricultural prices decline by more and the losses to farmers in non-insulating Australasia are increased by all measures. Indeed, measured in terms of real returns to land and agricultural capital, Australasian farmers' losses from the medium run effects of the Asian recession double. ${ }^{40}$

The extent of such insulation might, therefore, have saved some northern farmers from the direct effects of the Asian recession but it imposed on their economies the greater burden of increased trade distortion and hence it enlarged the gap to be spanned by the next round of trade negotiations. In those regions where no such insulation took place, farmers have borne the substantial adjustment costs highlighted here. Those among them who nonetheless enjoy government assistance might therefore be expected to view with less favour any further adjustment costs associated with the removal, or scaling back, of existing protections.

\section{Asian Recession Effects and the Scale of Agricultural Trade Reform}

The pattern of agricultural trade distortions as of 1995 is built into the GTAP Version IV database, derived for OECD countries from PSE and CSE estimates of the type listed in Table 11. The resulting 1995 ad valorem tariff and export subsidy equivalents are listed in Table 12. From this pattern it is evident that agricultural trade in developing Asia and Japan remained quite distorted with rates that were highest in the cereals and livestock industries.

\footnotetext{
${ }^{38}$ For this observation we are indebted to Sam Laird. See Laird (1999).

${ }^{39}$ For a thorough review of the implementation of the Uruguay Round Agreement on Agriculture, see Josling and Tangermann (1999). More detail about its implementation in the EU is provided by Swinbank (1999).

${ }^{40}$ Details from this simulation are available on request from the authors.
} 
The region is not homogeneous, however. In Korea, where tariff and export subsidy equivalents had been extremely high in the Uruguay Round benchmark period, rates had fallen by half in the decade to 1995 .

In Japan, on the other hand, no significant decline was apparent in this period. Indeed, part of the home agricultural price rises associated with the depreciation of the Yen in 1997-98 appear to have been passed through to farmers in rejection of an important opportunity for reform. Indeed, Japanese agricultural protection rates rose during this period. ${ }^{41}$ Not least in Japan, but also elsewhere in recessed Asia, the recession depreciated the domestic currency and raised home agricultural prices relative to prices in less traded sectors. It therefore offered an opportunity to reduce agricultural distortions permanently. At the fixed ad valorem protection rates assumed in our analysis of the Asian recession, the substantial real depreciations these economies experienced appear to have greatly enhanced both the welfare and the international competitiveness of their farmers.

The main threat to further global agricultural trade reform, however, is in the northern regions and, most particularly, the EU. There, ad valorem rates of protection remained very high in 1995 . In the face of the real appreciation that came with the Asian recession, EU rates of protection rose on average, as indicated in Table 11. To compare the effects of a substantial future liberalisation with those associated with the Asian recession, we implement a simple global liberalisation of all agricultural distortions by 50 per cent of the ad valorem rates indicated in Table $12 .^{42}$ We use the same model as for our Asian recession experiment in the previous section and, for comparability, we retain the assumption that capital is immobile between industries. Unlike the Asian recession experiments, however, there are no associated shocks to the capital account. In this case we are asking how different the world of 1995 would have been had there been only half the agricultural protection in all regions. The average rate of saving in each region is therefore fixed at its 1995 level and the regional distribution of investment is endogenous. While the liberalisation shock does cause substantial terms of trade changes, the associated real capital account changes, and hence changes to real exchange rates, are therefore minimal.

\footnotetext{
${ }^{41}$ See OECD (1999), Appendix III.

${ }^{42}$ More than a 50\% liberalisation of agricultural distortions is extremely unlikely. More than that would, in any case, be difficult to justify as first best reform given the substantial size of services sectors and the as yet poorly measured barriers to trade therein.
} 
The resulting changes in real unit factor rewards are presented in Table 13. The regional pattern emerging depends on the extent of the domestic distortions removed and on any terms of trade gains or losses. Factors, such as land and agricultural capital, which previously gained from protection, clearly lose from its removal. In the EU they lose substantially. This is despite increases in traded agricultural commodity prices arising out of the collective nature of the liberalisation in this experiment. ${ }^{43}$ Disappointingly, virtually no primary factors enjoy real gains in the EU and the US, the two regions that will be the principal protagonists in the new round.

Leaving aside its domestic political implications, this result appears more pessimistic than it really is. Both the US and the EU do experience small real GDP gains from the liberalisation. These occur in spite of the declines in unit factor rewards because a substantial part of the agricultural distortions in the EU and the US are either export subsidies or deficiency payments, both of which burden the tax-payer. When these distortions are reduced there is a large increase in net government revenue, sufficient to convert a decline in GDP at factor cost into a rise in real GDP. In addition, the increases in GDP thus calculated tend to underestimate the gains from agricultural reform. This is because, in this model, government revenue is raised by lump sum taxes and so it incurs no dead weight loss in our analysis. In reality, the recoupment of such losses would be a major part of any potential gains from liberalisation that would be enjoyed in the EU and the US.

In recessed Asia, a high average level of pre-existing agricultural protection ensures that factors other than land are significant gainers from the liberalisation. At the same time, because the liberalisation raises traded agricultural prices, China and Australasia enjoy relatively substantial terms of trade gains that ultimately favour both their farmers and their workers. However, many of the countries in the recessed part of Asia have strong farm lobbies, borne out of rapid overall economic growth and relative agricultural contraction. They have not been active in promoting the cause of agricultural liberalisation. A prominent case in point is China where there is widespread concern about declining agricultural selfsufficiency. This follows the East Asian pattern of commercial policy reform and infrastructural development revealing the economy's comparative disadvantage in agriculture. Meanwhile, as farmer numbers contract their political cohesion increases and pressure on

\footnotetext{
${ }^{43}$ Where protection is the more prevalent distortion, unilateral liberalisation by any single region always imposes high losses on previously assisted factors by comparison with multilateral liberalisation. See Tyers
} 
provincial and national governments for protection mount. In spite of the potential economywide gains the above results suggest that China might enjoy from a global liberalisation it is therefore unlikely to support a more liberal trade regime for agriculture.

In the important case of the EU, in spite of the very large diminution in farmer welfare that a 50 per cent liberalisation would bring, the effects of the Asian recession shock are not insignificant by comparison. Had that shock been passed through to farmers, their real return on land would have fallen by 15 per cent of the hypothetical liberalisation decline. The corresponding percentage for returns to capital specific to cereals is eight per cent, other crops 63 per cent, livestock products 12 per cent and other agriculture 67 per cent. In effect, whether passed through or not, the Asian recession has raised the stakes for European farmers by these proportions.

\section{Conclusion}

By forcing a sudden enlargement of Asian current account surpluses, the Asian recession has reduced global demand for agricultural commodities and caused international trading prices to fall. While there have been associated declines in Asian demand for other tradeable goods, that for agricultural commodities as a group is the largest. This is because the surge in Asian, mainly manufactured, exports that has been part of the recovery phase has drawn into the recessed Asian economies imported intermediate inputs that comprise mainly mineral, energy and manufactured products. Outside Asia, unless government policies have effectively insulated them, farmers have been the principal losers from the Asian recession. Had no northern farmers been insulated by changes in their governments' policies, the losses those farmers would have endured, measured in terms of the real returns to land and sector specific capital, are substantial. In the case of the highly protected farmers of the EU, the losses range between eight per cent and two thirds of those that would be endured were there to be a reduction by half in the tariff and export subsidy equivalents of the instruments now protecting them.

Even if farmers in such regions have been insulated, and the evidence suggests that those in the EU and some other regions have, the scale of the protection they receive has thereby been expanded, leaving a more daunting task for future rounds of trade negotiations. And it is likely that the effects of the Asian recession will be long lasting. The global 
redistribution of investment that has occurred since 1997, and which is given emphasis in our analysis, will probably never be fully reversed. Effects of the type simulated here will quite likely be felt through the next round of negotiations. Yet this is no reason not to pursue agricultural reform in the Millennium Round. It is true that more open northern markets for all goods and services, and particularly Asia's mainly manufactured exports, will aid Asia's adjustment. This means that, since northern farmers have been the principal northern losers from the Asian recession, they have an interest in the extension of the "Built-in Agenda" to incorporate trade in manufactured products.

The machinery for future reductions in agricultural protection was incorporated into the WTO during the Uruguay Round. The further discussions as part of the WTO's Built-in Agenda, incorporate trade in agriculture, services and intellectual property. They will consolidate this machinery. The rise in protectionist sentiment amongst northern farmers, as induced in part by the effects of the Asian recession, will be a challenge for its implementation, however. That challenge will be less insurmountable if a full round is undertaken and there is the opportunity for net gains to be made by all participating countries.

\section{References:}

Adams, P.D., "Computable general equilibrium analysis of the consequences for Australia of the Asian crisis", Centre of Policy Studies, Monash University, 1998.

Bayoumi, T. and C. Towe, "Macroeconomic developments and prospects", in IMF, Selected Issues, Staff Country Report, Washington DC: July 1998.

Chang, R. and A. Velasco, "Financial crises in emerging markets: a canonical model", NBER Working Paper 6606, Cambridge, Massachusetts, June 1998, http://www.nber.org/papers/w6606.

Corbett, J. and D. Vines, "The Asian Crisis: lessons from the collapse of financial systems, exchange rates and macroeconomic policy", Chapter 2 in R. Agenor, M. Miller, D. Vines and A. Weber (eds.) The Asian Financial Crisis: Causes, Contagion and Consequences, Cambridge: Cambridge University Press, forthcoming 1999.

Corsetti, G., P. Pesenti and N. Roubini, "What caused the Asian currency and financial crisis?", Department of Economics, New York University, March 1998.

Coyle, W.T., W.J. McKibbin and Z. Wang, "The Asian financial crisis: effects on US agriculture", Staff Paper No.9805, Market and Trade Economics Division, Economic Research Service, US Department of Agriculture, Washington DC 1999.

DFAT, "Global trade reform: maintaining momentum", Department of Foreign Affairs and Trade, Government of Australia, Canberra, 1999.

Engel, C.M., "Exchange rates and prices", NBER Reporter, Winter 1998-99, pp 13-17, Cambridge Massachusetts: National Bureau of Economic Research, 1999. 
Gehlhar, M. 'Economic growth and trade in the Pacific rim: an analysis of trade patterns', doctoral dissertation, Purdue University, 1994.

Gehlhar, M.J., T.W. Hertel and W. Martin, "Economic growth and the changing structure of trade and production in the Pacific Rim", American Journal of Agricultural Economics, 76(5): 1101-1110, December 1994.

Goldstein, M., The Asian Financial Crisis: Causes, Cures and Systemic Implications, Policy Analysis in International Economics No.55, Institute for International Economics, Washington, DC, June 1998.

Hertel, T., W. Martin, Y. Yanagishma and B. Dimaranan, "Liberalising manufactures trade in a changing world economy", Chapter 7 in W. Martin and L.A. Winters (eds.), The Uruguay Round and the Developing Countries, Cambridge University Press 1996.

Hertel, T.W. and M.E. Tsigas, "Structure of GTAP" in T.W. Hertel (ed.), Chapter 2 of Global Trade Analysis Using the GTAP Model, New York: Cambridge University Press, 1997, pp 13-73.

Hertel, T.W. (ed.), Global Trade Analysis Using the GTAP Model, New York: Cambridge University Press, 1997.

Horiuchi, A., "Japan". Chapter 12 in McLeod, R. and R. Garnaut (eds.) op cit.

Huang, Y. and L. Song, "China in the aftermath of the East Asian financial crisis", Presented at the conference on "International Capital Mobility and Domestic Economic Stability", hosted by the Reinventing Bretton Woods Committee and the World Bank, Australian National University, Canberra, July 1999.

IMF, World Economic Outlook, International Monetary Fund, Washington DC, October 1998.

IMF, World Economic Outlook, International Monetary Fund, Washington DC, May 1999.

Josling, T. and S. Tangermann, "The WTO agreement on agriculture and the next negotiating European Review of Agricultural Economics, 26(3): 271-388, September 1999.

Krueger, A.O., M. Schiff and A. Valdes, "Measuring the effects of intervention in agricultural prices", Chapter 1 in A.O. Krueger, M. Schiff and A. Valdes (eds.) The Political Economy of Agricultural Pricing Policy, Johns Hopkins University Press for the World Bank, 1991 pp 1-14.

Krugman, P, "The myth of Asia's miracle", Foreign Affairs, 1994.

"Balance sheets, the transfer problem and financial crises", paper prepared for festschrift in honour of Robert Flood, January 1999a, http://web.mit.edu/krugman/www/whatsnew.html.

"Recovery? Don't bet on it", Time Magazine Asia, 21 June 1999b, www.pathfinder.com/time/asia/magazine/1999/990621/cover1.html.

Laird, S., "Millennium Round negotiations on market access in goods and services", paper presented at the $24^{\text {th }}$ annual conference of the UK International Economics Study Group, University of Birmingham, September 1999.

Lane, T., A.R. Ghosh, J. Hamann, S. Phillips, M. Schulze-Ghattas and T. Tsikata, "IMFsupported programs in Indonesia, Korea and Thailand: a preliminary assessment". IMF, Washington DC, Jan 1999.

McDougall, R.A., A. Elbehri and T.P. Truong (eds.) Global Trade, Assistance and Protection: The GTAP 4 Database, Center for Global Trade Analysis, Purdue University, December 1998.

McKibbin, W.J., "The crisis in Asia: an empirical assessment", Brookings Discussion Paper in International Economics 136, Washington DC: The Brookings Institution, 1998a. 
, "Internationally mobile capital and the global economy", Chapter 14 in McLeod and Garnaut (eds.) op cit pp 227-244, 1998b.

McLeod, R.H. and R. Garnaut (eds.), East Asia in Crisis: from being a miracle to needing one, London: Routledge 1998.

Noland, M., L. Liu, S. Robinson and Z. Wang, Global Effects of the Asian Currency Devaluations, Policy Analysis in International Economics No.56, Institute for International Economics, Washington, DC, July 1998.

Radelet, S. and J. Sachs, "The onset of the East Asian financial crisis", Harvard Institute for International Development, February 1998.

OECD (1998), “Agricultural policy reform: stocktaking of achievements", Discussion Paper for Meeting of the Committee for Agriculture at Ministerial Level, Paris 5-6 March, 1998.

OECD (1999) Agricultural Policy in OECD Countries: Monitoring and Evaluations 1999, Paris, 1999.

Schiff, M. and A. Valdes, "Agriculture and the macroeconomy", Working Paper No.1967, World Bank, Washington DC, September 1998.

Suryahadi, A.Y., "The effects of openness on developing country labour markets: the case of Indonesia", doctoral dissertation, Australian National University, December 1998.

Swinbank, A. "CAP reform and the WTO: compatibility and developments", European Review of Agricultural Economics, 26(3): 389-408, September 1999.

Tyers, R. and K. Anderson, Disarray in World Food Markets: A Quantitative Assessment, Cambridge University Press, 1992.

Wong, K.Y. (ed.), “The Asian crisis: what has happened and why? Economics, University of Washington, Seattle, August 1998.

World Bank, "The crisis pictured", Asiaweek, April 16, 1999, as presented on the web site: www.pathfinder.com/asiaweek/99/0416/cs3a_crisis.html.

Yang, Y. and R. Tyers, "The Asian recession and northern labour markets", Working Papers in Economics and Econometrics No. 372, Australian National University, Canberra, May 1999 (downloadable from http://ecocomm.anu.edu.au/departments/ ecoh/staff/tyers.html). 
Figure 1: Agricultural commodity prices, 1980-99 (1990=100)

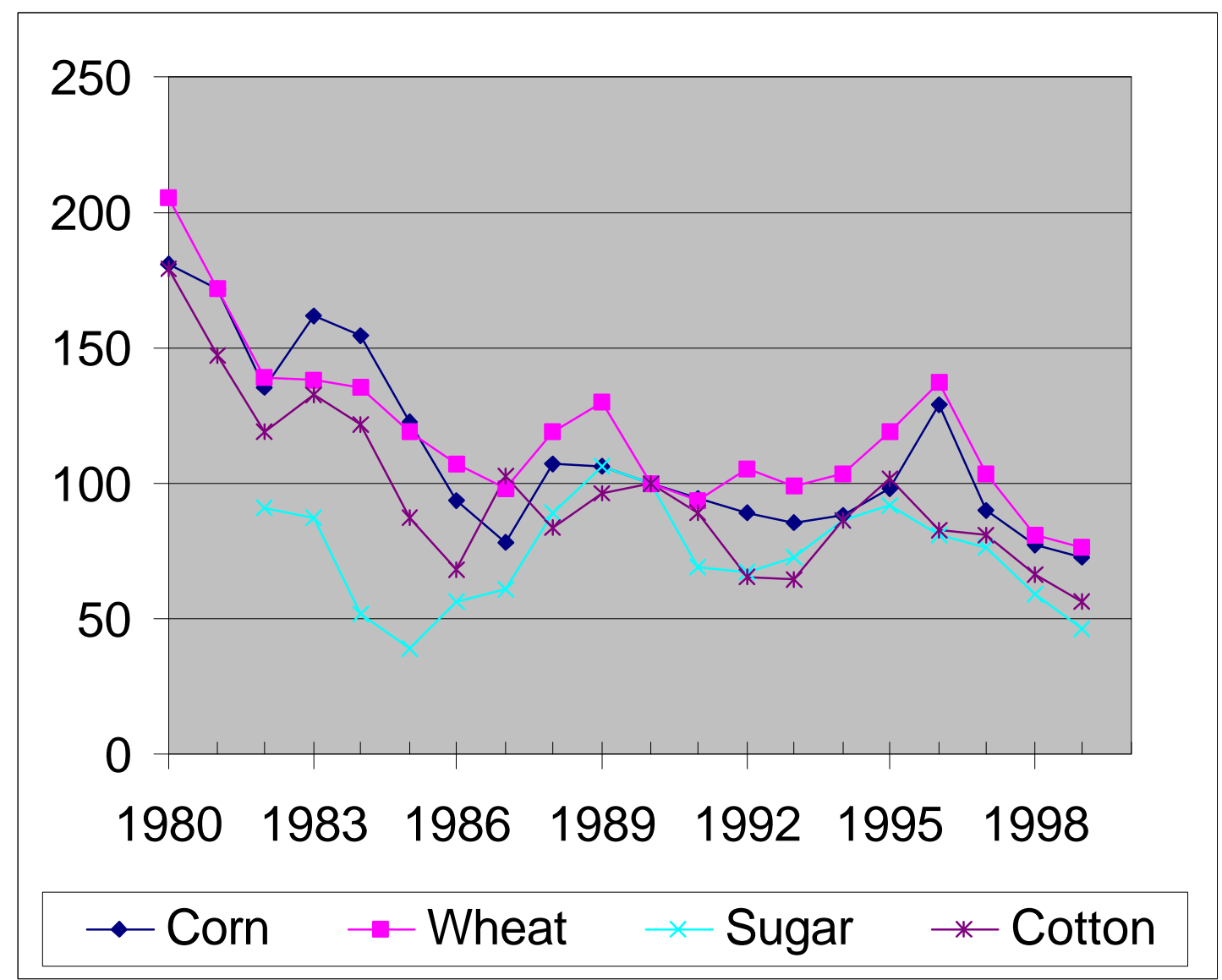

Note: Nominal prices are deflated by the US GDP deflator.

Source: Global Commodity Markets, April 1999, World Bank, Washington, D.C.World Bank, Commodity Markets and the Developing Countries (various issues) and Global Commodity Markets, April 1999, World Bank, Washington, D.C. 
Table 1: Factor proportions in the EU, per cent ${ }^{\mathrm{a}}$

\begin{tabular}{|c|c|c|c|c|c|c|}
\hline Sector & Land & Labour & Skill & Capital & $\begin{array}{c}\text { Nat. } \\
\text { Rescs }\end{array}$ & Total \\
\hline Agriculture & $10(7)$ & $58(53)$ & $4(11)$ & $24(26)$ & $4(3)$ & 100 \\
\hline Mining & $0(0)$ & $17(24)$ & $9(14)$ & $38(37)$ & $36(25)$ & 100 \\
\hline Manufacturing: & $0(1)$ & $57(50)$ & $20(21)$ & $23(27)$ & $0(1)$ & 100 \\
\hline skill intensive & $0(0)$ & $48(45)$ & $26(26)$ & $26(29)$ & $0(0)$ & 100 \\
\hline labour intensive & $0(0)$ & $41(41)$ & $17(20)$ & $42(39)$ & $0(0)$ & 100 \\
\hline skill intensive & $0(0)$ & $34(36)$ & $36(33)$ & $30(31)$ & $0(0)$ & 100 \\
\hline
\end{tabular}

a Listed are value added shares with, in parentheses, total factor proportions (including the factor content of intermediate inputs).

Source: GTAP Database Version 4.1. See McDougall et al. (1998). 
Table 2: Model analytics:

Single household in each region.

Utility Cobb-Douglas in:

private household expenditure

government expenditure

savings (share and marginal propensity can be modified exogenously)

Government consumption: Cobb-Douglas composite of all goods.

Private household consumption: $\mathrm{CDE}^{\mathrm{a}}$ expenditure function.

CES decomposition between home goods and imports

CES decomposition of imports by region of origin.

Firms are perfectly competitive with constant returns to scale.

Technology is a CES combination of intermediate inputs

with a separate CES composite of primary factors.

Intermediate demand is decomposed to home goods and imports as for household

final consumption.

Primary factor demand : nested CES system ${ }^{c}$.

Factor specificity: Land specific to agriculture

Natural resources specific to mining

Physical capital is sector specific

Labour and skill intersectorally mobile.

Primary factor supply: all factors are inelastic in supply.

Capital returns are intra-regional.

Investment: worldwide sum across regions' savings.

Does not affect the current productive capital stock.

Does consume "capital goods" and enter the capital account of each region's balance of payments.

Capital goods are a Cobb-Douglas composite of domestic goods and services.

The endogenous allocation of investment across "non-Asia" equalises "expected returns" in each region. These are a decreasing function of regional investment. $^{\mathrm{d}}$

a Constant Difference of Elasticities. See Hertel (1997).

b Households can transform labour between skilled and unskilled. However, this capability is reduced to negligibility in the applications discussed in this paper.

c For the primary factor demand structure, see Figure 1 in Yang and Tyers (1999).

d The formulation of expected returns, along with some alternative investment allocation rules, is

discussed in Hertel and Tsigas (1997: 54-60). 
Table 3: Model structure

\begin{tabular}{|c|c|}
\hline Regions & Share of world GDP ${ }^{f}$ \\
\hline 1. Recessed developing Asia ${ }^{a}$ & 5.1 \\
\hline 2. Japan & 18.0 \\
\hline 3. China ${ }^{b}$ & 2.5 \\
\hline 4. European Union ${ }^{\mathrm{c}}$ & 29.0 \\
\hline 5. United States & 25.2 \\
\hline 6. Australasia & 1.4 \\
\hline 7. Rest of world & 18.8 \\
\hline \multicolumn{2}{|l|}{ Primary factors } \\
\hline 1. Agricultural land & \\
\hline 2. Natural resources & \\
\hline 3. Skill ${ }^{\mathrm{d}}$ & \\
\hline 4. Labour ${ }^{\mathrm{d}}$ & \\
\hline 5. Physical capital & \\
\hline
\end{tabular}

Sectors ${ }^{\mathrm{e}}$

1. Cereals (paddy and processed rice, wheat and other cereals)

2. Other crops (vegetables, oil seeds, processed vegetable oils, sugar cane and sugar, crop based fibres and other crops)

3. Livestock products (bovine cattle, meat and meat products, raw milk and dairy products, animal fibres and other animal products)

4. Other agricultural products (forest products, fish and other agricultural products)

5. Mining and energy (coal, oil, gas and other minerals)

6. Skill-intensive manufacturing (petroleum, paper, chemicals, processed minerals, metals, motor vehicles and other transport equipment, electronic equipment and other machinery and equipment)

7. Labour-intensive manufacturing (textiles, apparel, leather and wood products, metal products, other manufactures)

8. Skill-intensive services (electricity, gas, water, financial services and public administration)

9. Labour-intensive services (construction, retail and wholesale trade, dwellings)

\footnotetext{
a Korea (Rep.), Indonesia, Philippines, Malaysia, Singapore, Thailand, Vietnam.

b China includes Hong Kong and Taiwan.

c The European Union of 15.

d The labour disaggregation is based on the ILO Classification of Occupations. Professional workers are defined as including managers and administrators, professionals and para-professionals. Production workers are plant and machine operators and drivers, tradespersons, clerks, labourers and related workers, salespersons and personal service workers.

e These are aggregates of the 50 sector GTAP Version 4 database. See McDougall et al. (1998).

f Share of 1995 GDP in US\$ measured at market prices and exchange rates.
} 
Table 4: Elasticities of substitution in intermediate and primary factor demand ${ }^{\mathrm{a}}$

\begin{tabular}{|c|c|c|c|}
\hline Sector & $\begin{array}{l}\text { In product } \\
\text { demand, } \\
\text { between } \\
\text { domestic and } \\
\text { imported }\end{array}$ & $\begin{array}{l}\text { In import } \\
\text { demand, } \\
\text { between regions } \\
\text { of origin }\end{array}$ & $\begin{array}{l}\text { In factor } \\
\text { demand, } \\
\text { between } \\
\text { primary factor } \\
\text { groups }\end{array}$ \\
\hline Cereals & 8.8 & 17.6 & 0.2 \\
\hline Other crops & 6.0 & 12.0 & 0.6 \\
\hline Livestock products & 5.2 & 10.5 & 0.4 \\
\hline Other agriculture & 4.8 & 9.6 & 0.8 \\
\hline Mining & 2.8 & 5.6 & 0.2 \\
\hline Manufacturing: labour intensive & 3.0 & 6.4 & 1.2 \\
\hline \multirow{3}{*}{$\begin{array}{l}\text { skill intensive } \\
\text { labour intensive } \\
\text { skill intensive }\end{array}$} & 2.8 & 6.0 & 1.2 \\
\hline & 1.9 & 3.8 & 1.5 \\
\hline & 2.0 & 3.8 & 1.3 \\
\hline
\end{tabular}

a These are group-specific weighted averages across the 50 industries defined in the database. The structure of intermediate and primary factor demand is indicated in Figure 1. The CDE parameters governing substitution in final demand are discussed in McDougall et al. (1998). Substitution elasticities in intermediate product demand, and between intermediates and primary factors, are set to unity (Cobb-Douglas) in this analysis.

b The elasticity of substitution within the labour group, between skilled and unskilled labour, is set at unity. Households' corresponding elasticity of transformation between skilled and unskilled labour is set to negligibility for this analysis.

Source: GTAP Database Version 4.1. See McDougall et al. (1998). 
Table 5 Medium run Asian recession shocks and closure ${ }^{\mathrm{a}}$

\section{Recessed developing Asia:}

Regional investment is exogenous and reduced from 1995 to 1998 levels.

The average regional saving rate is now made exogenous at the value achieved in the

short run solution. ${ }^{\mathrm{b}}$ The trade balance (X-M) is endogenous.

Sectoral production volumes are endogenous, while sectoral capital use is exogenous.

Labour and land productivity in agriculture are restored to reference levels.

Labour (skilled and unskilled) remains sectorally mobile and is fully employed.

Agricultural and other policies maintain constant nominal protection coefficients. ${ }^{\mathrm{f}}$

\section{Japan:}

Regional investment is exogenous and reduced from 1995 to 1998 levels.

The average regional saving rate is now made exogenous at the value achieved in the short run solution. ${ }^{\mathrm{b}}$ The trade balance $(\mathrm{X}-\mathrm{M})$ is endogenous.

Sectoral production volumes are endogenous, while sectoral capital use is exogenous.

Labour (skilled and unskilled) remains sectorally mobile and is fully employed.

Agricultural and other policies maintain constant nominal protection coefficients. ${ }^{\mathrm{f}}$

\section{China:}

Regional investment is endogenous, equalising regional average "expected returns" across China, EU, US, Australasia and the rest of the world. ${ }^{\mathrm{c}}$

The average rate of saving is endogenous, while the current account surplus (X-M) is made exogenous and shocked as per the observed 1998 change.

Sectoral production volumes are endogenous, while sectoral capital use is exogenous.

Labour (skilled and unskilled) remains sectorally mobile and is fully employed.

Agricultural and other policies maintain constant nominal protection coefficients. ${ }^{\mathrm{f}}$

\section{EU, Australasia:}

Regional investment is endogenous to equalise regional average "expected returns" across EU, US, Australasia and the rest of the world. ${ }^{c}$

The trade balance is endogenous, while the average savings rate is retained exogenous.

Sectoral production volumes are endogenous, while sectoral capital use is exogenous.

Labour (skilled and unskilled) remains sectorally mobile and the real wage of raw labour is flexible upward only. ${ }^{\mathrm{e}}$

Agricultural and other policies maintain constant nominal protection coefficients. ${ }^{f}$

\section{US, and rest of world:}

Regional investment is endogenous to equalise regional average "expected returns" across EU, US, Australasia and the rest of the world. ${ }^{c}$

The trade balance is endogenous, while the average savings rate is retained exogenous.

Sectoral production volumes are endogenous, while sectoral capital use is exogenous.

Labour (skilled and unskilled) remains sectorally mobile and both real wages are flexible.

Agricultural and other policies maintain constant nominal protection coefficients. ${ }^{\mathrm{f}}$

a In both the short and medium run, capital is completely sector specific in all regions, so that the rate of return differs across sectors.

b Since the capital account and current account must be equal in magnitude and opposite in sign, I$\mathrm{S}=\mathrm{M}-\mathrm{X}$. For both developing Asia (incl. China) and Japan, these changes impose explicit contractions in investment and rises in the average rate of saving, balanced by a now endogenous rise in exports relative to imports. Details of the short run solution are available in Yang and Tyers (1999).

c See Table 2 for further explanation.

e In the end, this constraint does not bind since both real wages rise.

f Since home products are differentiated from imports, the ratio of home goods prices and import prices does vary. That between home goods prices and export prices remains fixed, however.

Source: IMF $(1998,1999)$, web site of Statistics Indonesia and that of MITI in Japan, 1997-98 changes. 
Table 6: Medium run changes in the balance of payments and the real exchange rate following the recession in developing Asia and Japan, 1995 US\$ billion $^{\mathrm{a}}$

\begin{tabular}{|c|c|c|c|c|c|c|c|}
\hline Sector & $\begin{array}{l}\text { Dev. } \\
\text { Asia }^{\mathrm{b}}\end{array}$ & Japan & China & USA & EU & $\begin{array}{c}\text { Austra } \\
\text {-lasia }\end{array}$ & $\begin{array}{c}\text { Rest of } \\
\text { world }\end{array}$ \\
\hline Capital account surplus (I-S) & -184 & -259 & -5 & 127 & 198 & 10 & 113 \\
\hline Investment, I & -105 & -202 & 11 & 140 & 217 & 10 & 125 \\
\hline Saving, $\mathrm{S}$ & 79 & 57 & 16 & 13 & 19 & 1 & 11 \\
\hline Current account deficit (M-X) & -184 & -259 & -5 & 127 & 198 & 10 & 113 \\
\hline Imports, $\mathrm{M}$ & -90 & -80 & 1 & 72 & 117 & 4 & 59 \\
\hline Exports, $\mathrm{X}$ & 94 & 179 & 6 & -55 & -81 & -6 & -54 \\
\hline $\begin{array}{l}\text { Real appreciation, } \%^{\mathrm{c}} \\
\quad \text { relative to developing } \text { Asia }^{\mathrm{d}}\end{array}$ & 0.0 & -2.8 & 5.4 & 9.3 & 9.6 & 7.8 & 8.9 \\
\hline Terms of trade, $\%^{\mathrm{d}}$ & -2.3 & -7.6 & 2.3 & 3.2 & 1.2 & 1.8 & 0.9 \\
\hline
\end{tabular}

a Medium run closure details are indicated in Table 5.

b Recessed developing Asia, excluding China.

c Here the change in the real exchange rate is approximated by the per cent change in the ratio of the region's GDP deflator with that of developing Asia.

d Change in the value of exports at endogenous prices, weighted by fixed 1995 (base period) export volumes, divided by the value of imports, weighted by fixed 1995 import volumes.

Source: Model simulations described in the text.

Table 7: Medium run changes in real import and producer commodity prices following the recession in developing Asia and Japan, per cent ${ }^{\mathrm{a}}$

\begin{tabular}{|c|c|c|c|c|c|c|c|c|}
\hline Sector & & $\begin{array}{l}\text { Dev. } \\
\text { Asia }\end{array}$ & Japan & China & USA & $\mathrm{EU}$ & $\begin{array}{c}\text { Austra } \\
\text {-lasia }\end{array}$ & $\begin{array}{l}\text { Rest of } \\
\text { world }\end{array}$ \\
\hline \multirow[t]{2}{*}{ Cereals } & Import $^{\mathrm{b}}$ & 8.2 & 11.6 & 1.7 & -2.1 & -2.0 & -1.2 & -1.7 \\
\hline & Producer & 2.6 & 2.4 & -0.4 & -1.4 & -1.4 & -0.7 & -1.0 \\
\hline \multirow[t]{2}{*}{ Other crops } & Import $^{\mathrm{b}}$ & 7.6 & 10.2 & 1.2 & -2.1 & -2.2 & -1.5 & -2.0 \\
\hline & Producer & 4.9 & 5.4 & -0.6 & -1.7 & -1.3 & -1.5 & -1.0 \\
\hline \multirow[t]{2}{*}{ Livestock } & Import $^{\mathrm{b}}$ & 7.7 & 10.0 & 0.9 & -1.3 & -2.1 & -1.5 & -1.0 \\
\hline & Producer & 1.9 & 2.0 & -0.7 & -1.0 & -0.8 & -0.8 & -0.5 \\
\hline \multirow[t]{2}{*}{ Other agriculture } & Import $^{\mathrm{b}}$ & 6.7 & 9.4 & 0.1 & -2.9 & -2.3 & -2.3 & -1.1 \\
\hline & Producer & 2.5 & 2.1 & -0.9 & -1.2 & -0.8 & -1.6 & -1.0 \\
\hline \multirow[t]{2}{*}{ Mfg, labour int. } & Import & 4.9 & 9.3 & -2.4 & -3.6 & -3.3 & -2.4 & -1.9 \\
\hline & Producer & 3.1 & 1.3 & -0.3 & -0.7 & -0.5 & -0.7 & -0.5 \\
\hline \multirow[t]{2}{*}{ Mfg, skill int. } & Import & 4.3 & 10.4 & -1.6 & -4.3 & -3.9 & -2.6 & -1.8 \\
\hline & Producer & 2.9 & 2.0 & -0.2 & -0.9 & -0.7 & -1.0 & -0.6 \\
\hline
\end{tabular}

a Medium run closure details are indicated in Table 5. All price changes listed are measured relative to region-specific GDP deflators.

b Import prices are here a CES index of source-specific prices excluding intra-regional trade.

Source: Model simulations described in the text. 
Table 8: Medium run changes in gross sectoral output and GDP following the recession in developing Asia and Japan, per cent ${ }^{\mathrm{a}}$

\begin{tabular}{|c|c|c|c|c|c|c|c|}
\hline Sector & $\begin{array}{l}\text { Dev. } \\
\text { Asia }\end{array}$ & Japan & China & USA & $\mathrm{EU}$ & $\begin{array}{c}\text { Austra } \\
\text {-lasia } \\
\end{array}$ & $\begin{array}{l}\text { Rest of } \\
\text { world }\end{array}$ \\
\hline Cereals & 1.0 & 0.0 & -0.4 & -1.5 & $\begin{array}{l}-1.8 \\
\end{array}$ & -0.2 & -0.9 \\
\hline Other crops & 1.5 & 0.3 & -0.7 & -1.5 & -1.5 & -2.0 & -0.6 \\
\hline Livestock & -0.1 & -0.9 & -1.3 & -0.6 & -0.7 & -0.5 & 0.0 \\
\hline Other agriculture & 0.3 & -0.5 & -1.2 & -1.1 & -1.1 & -3.5 & -1.0 \\
\hline Mining & 1.4 & 5.2 & 0.5 & -0.5 & -0.9 & -0.6 & -0.6 \\
\hline \multirow{2}{*}{$\begin{aligned} \text { Manufacturing: labour intensi } \\
\text { skill intensive }\end{aligned}$} & 7.3 & 2.0 & 1.0 & -1.0 & -0.4 & -0.7 & -0.8 \\
\hline & 3.6 & 5.0 & 0.6 & -1.1 & -1.6 & -1.1 & -0.7 \\
\hline labour intensive & -5.8 & -3.3 & 1.4 & 1.4 & 1.7 & 1.3 & 1.7 \\
\hline skill intensive & -2.3 & -1.4 & 0.2 & 0.2 & 0.2 & 0.2 & 0.1 \\
\hline GDP & -0.39 & -0.04 & 0.72 & 0.07 & 0.12 & 0.26 & 0.31 \\
\hline
\end{tabular}

a Medium run closure details are indicated in Table 5 .

Source: Model simulations described in the text.

Table 9: Medium run changes in real unit factor rewards, per cent ${ }^{\mathrm{a}}$

\begin{tabular}{|c|c|c|c|c|c|c|c|}
\hline Primary factor & $\begin{array}{l}\text { Dev. } \\
\text { Asia } \\
\end{array}$ & Japan & China & USA & EU & $\begin{array}{c}\text { Austra } \\
\text {-lasia } \\
\end{array}$ & $\begin{array}{c}\text { Rest of } \\
\text { world }\end{array}$ \\
\hline Labour & -2.0 & -0.9 & 1.0 & 0.6 & 0.4 & 0.7 & 0.8 \\
\hline Skill & -3.0 & -1.1 & 1.1 & 0.3 & 0.3 & 0.6 & 0.6 \\
\hline Natural resources & 3.5 & 5.9 & -0.3 & -2.1 & -3.0 & -2.8 & -2.4 \\
\hline Land & 3.7 & 2.9 & -2.8 & -3.8 & -4.5 & -3.2 & -1.7 \\
\hline Capital (regional average return) & -1.8 & -0.3 & 1.0 & 0.3 & 0.5 & 0.5 & 0.3 \\
\hline \multicolumn{8}{|l|}{ Capital specific to: } \\
\hline Cereals & 5.4 & 3.2 & -1 & -3.9 & -6.0 & -1.0 & -2.8 \\
\hline Other crops & 6.6 & 4.2 & -3 & -4.5 & -5.0 & -5.4 & -2.5 \\
\hline Livestock & 1.8 & 1.4 & -5 & -1.6 & -2.1 & -2.1 & -0.4 \\
\hline Other agriculture & 2.5 & 2.2 & -2 & -2.3 & -2.1 & -5.2 & -2.4 \\
\hline Mining & 8.8 & 13.6 & 1 & -2.2 & -3.1 & -2.5 & -2.5 \\
\hline \multirow[t]{2}{*}{ Manufacturing: } & 9.2 & 2.8 & 1 & -1.4 & -0.7 & -1.1 & -1.0 \\
\hline & 5.8 & 6.2 & 0 & -1.6 & -1.9 & -1.8 & -1.1 \\
\hline \multirow[t]{2}{*}{ Services: } & -5.7 & -2.6 & 1 & 1.2 & 1.4 & 1.2 & 1.8 \\
\hline & -2.4 & -1.7 & 0 & 0.1 & 0.0 & 0.1 & 0.2 \\
\hline
\end{tabular}

a Medium run closure details are indicated in Table 5. All entries are unit rewards relative to the region's consumer price index.

Source: Model simulations described in the text. 
Table 10: Manufactured imports in total cost, 1995, per cent ${ }^{\mathrm{a}}$

\begin{tabular}{|c|c|c|c|c|c|c|c|c|c|}
\hline & \multicolumn{3}{|c|}{ Japan } & \multicolumn{3}{|c|}{ Recessed dev. Asia } & \multicolumn{3}{|c|}{ China } \\
\hline Sector & $\begin{array}{l}\% \text { of } \\
\text { exports }\end{array}$ & $\begin{array}{c}\% \text { of } \\
\text { imports } \\
\text { in TC }\end{array}$ & $\begin{array}{c}\% \text { of } \\
\text { mfg } \\
\text { imports } \\
\text { in TC }\end{array}$ & $\begin{array}{l}\% \text { of } \\
\text { exports }\end{array}$ & $\begin{array}{c}\% \text { of } \\
\text { imports } \\
\text { in TC }\end{array}$ & $\begin{array}{c}\% \text { of } \\
\text { mfg } \\
\text { imports } \\
\text { in TC }\end{array}$ & $\begin{array}{c}\% \text { of } \\
\text { exports }\end{array}$ & $\begin{array}{c}\% \text { of } \\
\text { imports } \\
\text { in TC }\end{array}$ & $\begin{array}{c}\% \text { of } \\
\text { mfg } \\
\text { imports } \\
\text { in TC }\end{array}$ \\
\hline Agriculture & 0.4 & 7.9 & 0.2 & 6.3 & 8.3 & 2.3 & 5.0 & 5.1 & 3.1 \\
\hline Mining & 0.2 & 1.0 & 0.4 & 2.9 & 10.9 & 4.4 & 2.6 & 6.3 & 5.3 \\
\hline labour int & 6.9 & 4.8 & 2.5 & 19.1 & 22.8 & 19.2 & 46.4 & 13.6 & 12.4 \\
\hline skill int & 77.6 & 5.9 & 2.9 & 49.2 & 29.8 & 25.1 & 36.1 & 11.6 & 10.5 \\
\hline Services: labour int & 11.4 & 2.4 & 0.5 & 18.4 & 12.2 & 7.5 & 6.1 & 5.7 & 4.8 \\
\hline skill int & 3.5 & 1.6 & 0.4 & 4.1 & 10.1 & 5.9 & 3.8 & 7.1 & 3.6 \\
\hline
\end{tabular}

a Mfg is manufacturing and TC refers to total production cost.

Source: GTAP Database Version 4.1. See McDougall et al. (1998). 
Table 11: Observed ad valorem nominal assistance rates, per cent ${ }^{\mathrm{a}}$

\begin{tabular}{|c|c|c|c|c|c|}
\hline Primary factor & & $1986-88$ & $1991-93$ & 1997 & 1998 \\
\hline \multicolumn{6}{|l|}{ European Union } \\
\hline Wheat & Producer & 117 & 128 & 88 & 125 \\
\hline & & 45 & 38 & -3 & 11 \\
\hline
\end{tabular}

Consumer

Maize

Producer 111

119

$54 \quad 79$

8

6

$-1$

2

Consumer

Other grains

Producer $\quad 160$

172

124

208

13

13

2

8

Consumer

Sugar (refined equiv) Producer

113

347

210

55

75

238

169

210

Consumer

Milk

Producer 142

166

135

101

132

138

88

125

Consumer

Beef and veal

Producer 96

95

Consumer

All commodities Producer 86

86
73

88

61

83

63

30

48

Consumer

USA

Wheat

Producer 106

75

34

61

$-2$

$-1$

$-16$

$-20$

Consumer

Maize

Producer

64

Consumer

Other grains

Producer $\quad 75$

41

30

60

$-2$

$-3$

$-11$

$-15$

Consumer

Sugar (refined equiv) Producer

146
196

112

133

67

76

70

76 


\section{Consumer}

Milk

Producer 168

140

106

81

155

74

115

Consumer

Beef and veal

Producer

6

5

3

4

$-4$

$-7$

$-10$

$-10$

Consumer

$\begin{array}{cccccc}\text { All commodities } & \text { Producer } & 35 & 24 & 17 & 28 \\ & & 9 & 1 & -3 & 3\end{array}$

Consumer

a Shown are values of the Nominal Assistance Coefficient (NAC) minus one, expressed as per cent. The NAC is the ratio of the producer or consumer subsidy equivalent (in domestic currency) and the value of total farm receipts at international prices and excluding any budgetary support. It expresses the transfers to agriculture in relation to border prices.

Source: OECD (1999): Part III, Tables III.30, III.30, III.63, and III.64.

Table 12: Ad valorem import tariff and export subsidy equivalents, agricultural products, 1995 , per cent ${ }^{\mathrm{a}}$

\begin{tabular}{llccccccc}
\hline Sector & & $\begin{array}{c}\text { Dev. } \\
\text { Asia }\end{array}$ & Japan & China & USA & EU & $\begin{array}{c}\text { Austra } \\
\text {-lasia }\end{array}$ & $\begin{array}{c}\text { Rest of } \\
\text { world }\end{array}$ \\
\hline Cereals & Tariff & 113 & 471 & -9 & 1 & 54 & 0 & 5 \\
& Subsidy & 107 & 494 & -7 & 1 & 29 & 0 & -3 \\
\multirow{3}{*}{ Other crops } & Tariff & 10 & 18 & 18 & 9 & 11 & 3 & 25 \\
& Subsidy & -4 & 7 & 1 & 0 & 16 & 2 & -3 \\
\multirow{5}{*}{ Livestock } & Tariff & 28 & 68 & 7 & 7 & 52 & 11 & 25 \\
& Subsidy & 23 & 67 & -20 & 5 & 74 & 5 & 2 \\
\multirow{2}{*}{ Other agriculture } & Tariff & 14 & 5 & 19 & 2 & 7 & 4 & 13 \\
& Subsidy & -2 & 0 & 6 & -1 & -1 & -0 & -2 \\
\hline
\end{tabular}

a For the OECD countries, these are based on producer subsidy equivalent calculations. For regional aggregates such as the EU, these are the rates applicable to inter-regional trade. Intra-regional trade rates are excluded.

Source: GTAP Database Version 4.1. See McDougall et al. (1998).

Table 13: Changes in real factor rewards following the 50\% liberalisation of 1995 agricultural trade distortions, per cent ${ }^{\mathrm{a}}$

\begin{tabular}{llllllrl}
\hline Primary factor & $\begin{array}{c}\text { Dev. } \\
\text { Asia }\end{array}$ & Japan & China & USA & EU & $\begin{array}{c}\text { Austra } \\
\text {-lasia }\end{array}$ & $\begin{array}{c}\text { Rest of } \\
\text { world }\end{array}$ \\
\hline
\end{tabular}




\begin{tabular}{|c|c|c|c|c|c|c|c|}
\hline Labour & 2.8 & 1.1 & 0.1 & -0.4 & -0.5 & 0.3 & -0.2 \\
\hline Skill & 2.8 & 1.2 & -0.9 & -0.4 & -0.1 & 0.1 & -0.2 \\
\hline Natural resources & 2.7 & 1.1 & -0.7 & -0.6 & 0.1 & -3.8 & -0.3 \\
\hline Land & -2.8 & -12.4 & 10.5 & -1.2 & -34.4 & 7.9 & -0.7 \\
\hline Capital (regional average return) & 3.0 & 0.9 & -0.3 & -0.4 & -0.7 & 0.2 & -0.2 \\
\hline \multicolumn{8}{|l|}{ Capital specific to: } \\
\hline Cereals & -18.4 & -22.4 & 14.1 & 8.8 & -75.0 & -4.5 & 7.6 \\
\hline Other crops & 22.2 & -0.4 & 2.6 & -6.4 & -7.6 & -2.5 & -3.6 \\
\hline Livestock & 0.2 & -11.6 & 24.5 & 2.2 & -16.7 & 26.8 & 2.4 \\
\hline Other agriculture & 6.8 & -1.4 & 0.6 & -0.8 & -2.8 & -5.7 & -0.6 \\
\hline Mining & 0.3 & 0.8 & -0.9 & -0.2 & 1.0 & -4.0 & -0.1 \\
\hline \multirow{2}{*}{$\begin{array}{l}\text { Manufacturing: labour i } \\
\text { skill int }\end{array}$} & 0.3 & 0.7 & -1.8 & -0.2 & 0.7 & -2.5 & -0.1 \\
\hline & 0.3 & 0.6 & -0.8 & -0.2 & 0.6 & -2.5 & -0.2 \\
\hline \multirow[t]{2}{*}{ Services: } & 1.1 & 0.5 & 0.3 & 0.0 & 0.1 & 0.1 & 0.3 \\
\hline & 0.9 & 0.5 & 0.1 & -0.1 & 0.2 & -0.1 & 0.2 \\
\hline
\end{tabular}

a Medium run closure details are indicated in Table 5. All entries are unit rewards relative to the region's consumer price index.

b Capital is sector specific and hence has returns that differ by sector.

Source: Model simulations described in the text. 